\title{
Predicting Asian Soybean Rust Epidemics Based on Off-Season Occurrence and El Niño Southern Oscillation Phenomenon in Paraná and Mato Grosso States, Brazil
}

\author{
C. A. Minchio ${ }^{1}$, L. H. Fantin ${ }^{1}$, J. H. Caviglione ${ }^{2}$, K. Braga ${ }^{1}$, M. A. Aguiar e Silva ${ }^{1} \&$ M. G. Canteri ${ }^{1}$ \\ ${ }^{1}$ Agronomy Department, State University of Londrina, Londrina, Brazil \\ ${ }^{2}$ Metereological Department, Agronomic Institute of Paraná, Londrina, Brazil
}

Correspondence: Lucas Henrique Fantin, Agronomy department, State University of Londrina, Londrina, Brazil. Tel: 55-43-996-084-693. E-mail: fantinagro@gmail.com

\author{
Received: July 25, $2018 \quad$ Accepted: September 2, $2018 \quad$ Online Published: October 15, 2018 \\ doi:10.5539/jas.v10n11p562 URL: https://doi.org/10.5539/jas.v10n11p562
}

\begin{abstract}
The study aimed to propose models to predict Asian soybean rust epidemics based on both the occurrence of the disease in the period between seasons and the climate variability index, which is influenced by the El Niño Southern Oscillation (ENSO) phenomenon. The data used to develop these models were obtained from 11 crop seasons, distributed among six regions of Paraná and twelve regions of Mato Grosso which was determined by the National Institute for Space Research (INPE). The three-dimensional model was obtained from linear and quadratic polynomial regression analyses, considering the following climatic variables as independent ( $\mathrm{Y}$ axis): Rainfall (PP), Standardized Precipitation Index (SPI), Southern Oscillation Index (SOI) and Temperature on the sea surface (SST Niño 3.4). The independent variable (X axis) was the number of occurrences of rust in the off-season, and the dependent variable ( $\mathrm{Z}$ axis) was defined as rust occurrences during the season, which were reported by the Anti-rust Consortium. The best model that explains the epidemic of the disease during the season in Paraná state was composed by Rainfall or SST Niño 3.4 variable as the Y axis. The best model for Mato Grosso state used SST Niño 3.4 or SOI variable. The variable number of occurrences in the off-season significantly influenced the model, indicating the potential use of this variable and meteorological variables on a macro scale to predict epidemics even before the start of the season.
\end{abstract}

Keywords: off-season, epidemiology, Phakopsora pachyrhizi, predict

\section{Introduction}

Brazilian soybean production in the 2017/18 season has been estimated in 114.96 million tons, sowned in an area of approximately 35 million hectares. Paraná and Mato Grosso states were responsible for approximately $45 \%$ of total production of Brazil, which correspond to 50.7 million tons, averaging 3,407 kg ha-1 (CONAB, 2018). High productivity is linked to disease control. Asian soybean rust (ASR), caused by Phakopsora pachyrhizi Syd. \& P. Syd, is the main soybean disease in Brazil (Godoy et al., 2016).

The pathogen is considered an obligate parasite requiring the presence of a living host. Brazil established a period in which the cultivation of soybean is prohibited as an alternative attempt to reduce the inoculum and minimize the risks of the disease. Despite of management strategies, soybean rust epidemics has been occuring constantly in Brazil. Godoy, Bueno, and Gazzieiro (2015) reported that the presence of voluntary plants from fallen grains during harvesting could contribute to the maintenance of inoculum in production areas in the "off-season" period. The emergence of epidemics from this inoculum is mainly related to climatic factors such as rain, which provides favourable conditions for infection and disease progression (Del Ponte, Godoy, Canteri, Reis, \& Yang, 2006).

The main known source of inter-annual climate variability is the phenomenon called El Niño Southern Oscillation (ENSO), which is responsible for changes in global atmospheric flow (Kousky, Kayano, \& Cavalcanti, 1984; Kousky \& Cavalcanti, 1984). The effects of ENSO can be observed in the northern part of the northeast and in the south of Brazil. In the south, where Paraná State is located, the warm phase (El Niño) generally provides excess rainfall during the spring of the first year and then at the end of fall and beginning of 
winter in the second year. The cold phase (La Niña) presents precipitation below normal in the spring and early summer (Berlato, Farenzena, \& Fontana, 2005).

Forecasts of epidemics can be performed based on meteorological variables (Del Ponte \& Esker, 2008; Tao et al., 2009). One example is the monitoring of changes in climatic conditions and use of computing platforms that generate risk maps of epidemics. Usually, these forecasting models are based on meteorological variables such as relative humidity above $90 \%$ and air temperature to estimate the duration of the wet period (Canteri, Del Ponte, Godoy, \& Tsukahara, 2007; Reis, 2004). However, according to Reis (2009), these types of models do not consider the amount of initial inoculum, which can significantly alter forecasts. One way to estimate the amount of initial inoculum for biotrophic fungi would be to monitor the reported cases of the disease the "off-season". In Brazil, the Asian Soybean Rust Consortium-CAF (http://www.consorcioantiferrugem.net) is the main project that provides information on the occurrence of soybean rust throughout the national territory as a way to reduce yield losses causes by ASR. The consortium information is provided by network laboratories and researchers in the main growing regions (Asian Soybean Rust Consortium, 2015).

This study aimed to propose mathematical models to predict the occurrence of soybean rust epidemics in soybean crop based on both the number of occurrences in the off-season in the states of Mato Grosso and Paraná and the following climate indices: the inter-annual variability of rainfall, accumulated precipitation, standardized precipitation index (SPI), southern oscillation index (SOI) and temperature index at the sea surface (SST).

\section{Method}

\subsection{Meteorological Data}

Mathematical models to explain ASR epidemics for Paraná State were developed using meteorological data on the ENSO phenomenon, the main source of inter-annual climate variability that is responsible for changes in the global atmospheric flow (Kousky, Kayano, \& Cavalcanti, 1984; Kousky \& Cavalcanti, 1984). The effects of ENSO in Brazil can be observed in the northern part of the Northeast and in the South. In the South, the warm phase (El Niño) generally provides excess rainfall during the spring of the first year and then at the end of fall and beginning winter in the second year. In the cold phase (La Niña), precipitation is below normal in the spring and early summer (Berlato, Farenzena, \& Fontana, 2005). Data from the 2004/2005 to 2014/2015 seasons were used; they were derived from the Weather Forecasting and Climate Studies Center/National Institute for Space Research (CPTEC/INPE), National Institute of Meteorology (INMET) and State Centers/Regional meteorology, available at CPTEC/INPE website (http://www.cptec.inpe.br/clima).

The average accumulated precipitation $(\mathrm{mm})$ was calculated with the standardized index of precipitation (SPI) value to the timescale of three months (quarter), from January 1981 to 2015 , covering 124 quadrants $\left(2.5^{\circ} \times 2.5^{\circ}\right.$ latitude and longitude). The quadrants were contained within regions 68, 69, 70, 71, 80, 81, 82, 89, 90,91 and 98 for Mato Grosso State (Figure 1A) and regions 111, 112, 113, 115, 116 and 117 for Paraná State (Figure 1B) and (Inpe, 2015). This same division into six regions for the State of Paraná and 12 regions for the State of Mato Grosso guided all other data collection and calculations in preparation for this study. 


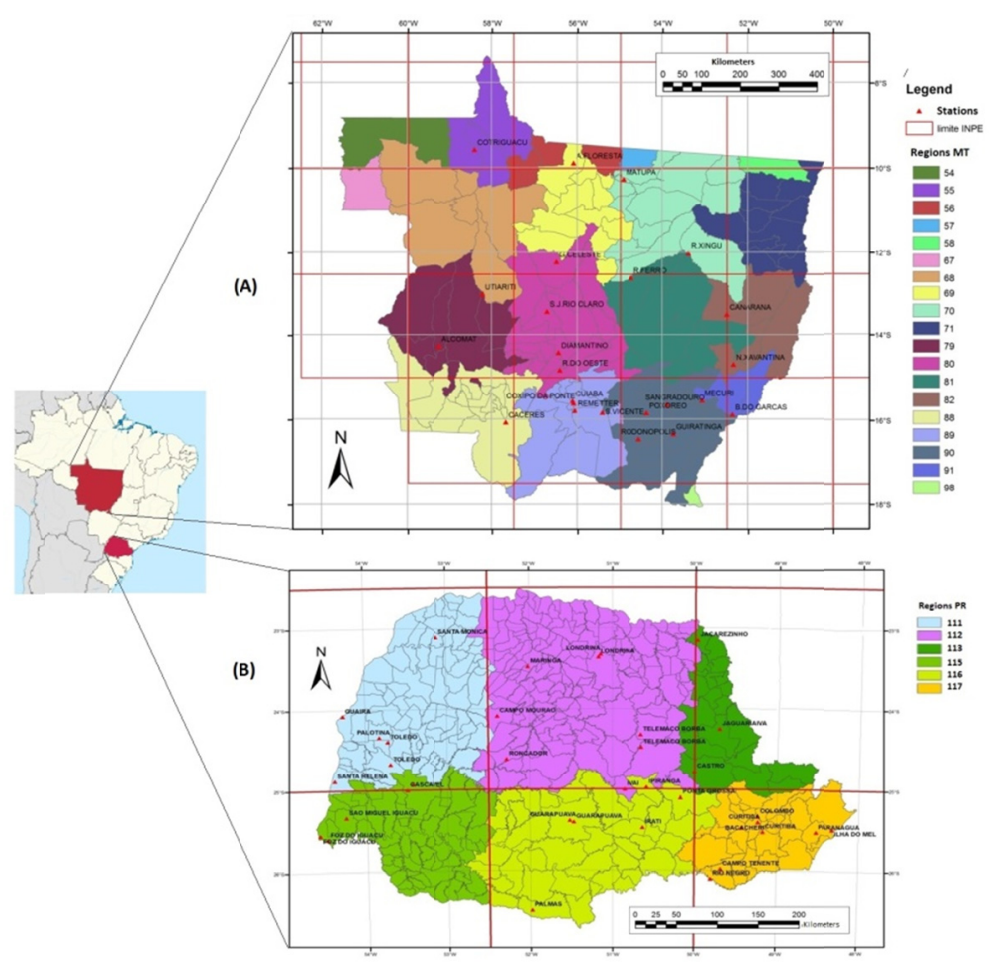

Figure 1. Regions and meteorological stations established by BRAZIL/INPE (2014), (A) State of Mato Grosso (MT) and (B) Paraná (PR)

\subsection{Asian Soybean Rust Occurrence Data}

The information associated with the occurrence of ASR symptoms in the states of Parana and Mato Grosso were obtained from the Asian Soybean Rust Consortium (http://www.consorcioantiferrugem.net) and comprehended the seasons 2004/2005 to 2014/2015. The collected data were grouped according to the region in which the city is contained. For the purpose of standardizing the rust occurrence reports, data were grouped in the form of quarters, forming groups NDJ (November-December-January), DJF (December-January-February), JFM (January-February-March), FMA (February-March-April), MAM (March-April-May), AMJ (April-May-June), MJJ (May-June-July), JJA (June-July-August), JAS (July-August-September), ASO (August-SeptemberOctober), SON (September-October-November), and OND (October-November-December). The "season" and "off-season" periods were defined according to Brazil/CONAB (2014); thus, tri-months MAM, AMJ, MJJ, JJA and JAS were off-season while ASO, SON, OND, NDJ, DJF, JFM and FMA were seasons.

\subsection{Statistical Analysis}

The mathematical models to explain epidemics were developed by linear and quadratic polynomial regression analyses using the software R (R Core Team, 2016). The three-dimensional model was built by SIGMAPLOT® software, considering the response variable as an estimated number of occurrences in the season period ( $\mathrm{Z}$ axis); the number of occurrences in the off-season period was the $\mathrm{X}$ axis, and the quarterly average values of climatic variability indices comprised the $\mathrm{Y}$ axis. Eight models were developed for each state of study. Climate variables used in the model development were season rainfall (PP), Standardized Precipitation Index (SPI-3 season), Southern Oscillation Index (SOI-3 season) and Temperature on the sea surface (SST Niño 3.4 season).

In addition, we considered the possibility that the value of the constant ("c") in the equation would be equal to zero, assuming the absence of disease without the initial inoculum and absence of environmental conditions that might cause the occurrence of infection (the parabola cuts the $\mathrm{Y}$ axis when $\mathrm{X}$ is equal to zero). The determination coefficient $\left(\mathrm{R}^{2}\right)$ determined the best model that explained the disease epidemics. The linear polynomial regressions that obtained a high coefficient of determination were applied to quadratic polynomial regression analysis, obtaining the three-dimensional models. 


\section{Results}

Data on the accumulated occurrences of ASR reported in the Asian Soybean Rust Consortium were gathered between the 2004/2005 to 2014/2015 seasons, considering all months of the year. In state of Paraná, the seasons 2008/09, 2007/08 and 2006/07 had the highest occurrences, in descending order (Figure 2).

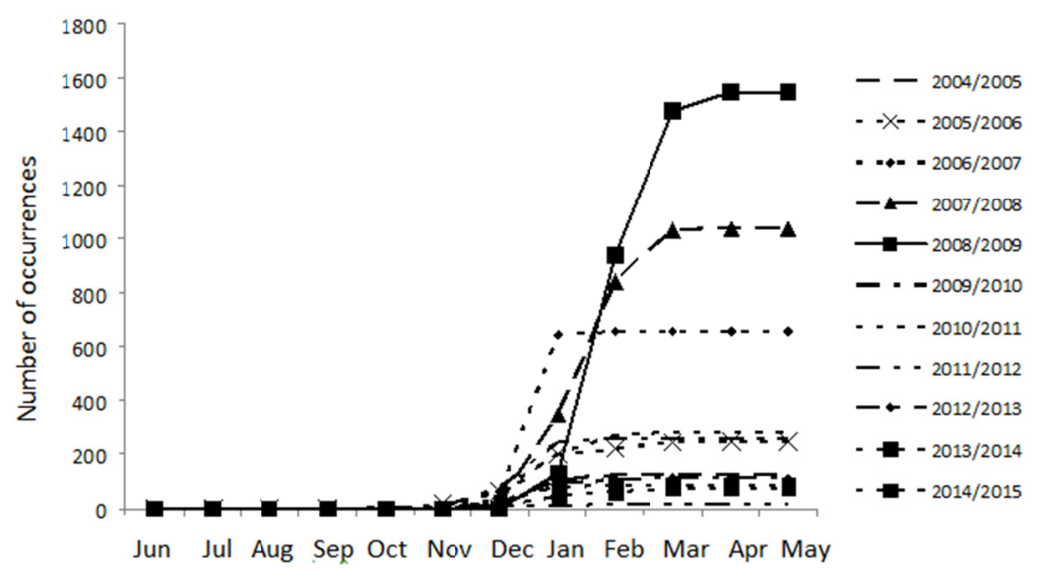

Figure 2. Cumulative Asian soybean rust occurrences in the seasons between 2004/2005 and 2014/2015 obtained from the antirust Consortium database for Paraná State (Asian Soybean Rust Consortium, 2015)

The first reports in the 2009/2010 season were described in September, while these reports began in October-November for the other seasons. The 2008/2009 season showed occurrences until May. In 2006/2007 season, the maximum events occurred in January, while for the 2007/2008 and 2008/2009 seasons, the maximum occurrences were in February. The same result was observed by Nascimento et al. (2012) working with spore trap. The 2006/2007 and 2009/2010 seasons were considered El Niño years. Thus, the higher occurrence of ASR was expected, but this was not observed. This finding can be explained by the fact that Paraná State is in the area of the division of influence of the El Niño phenomenon; thus, the increase in precipitation in these years did not always occur (Figure 3).

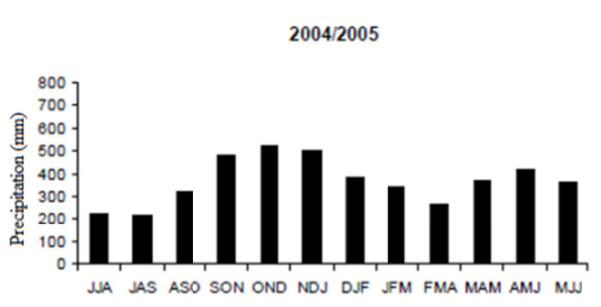

$2006 / 2007$

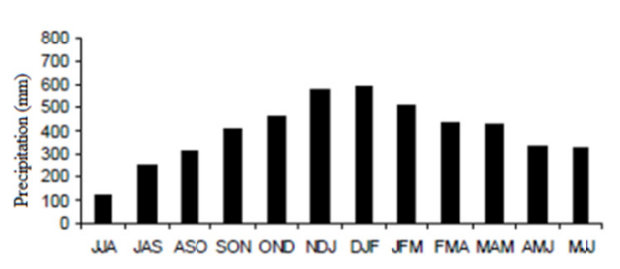

2005/2006

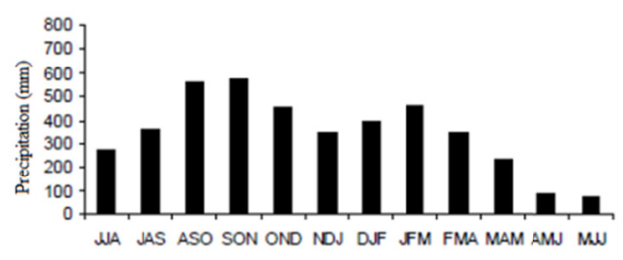

2007/2008

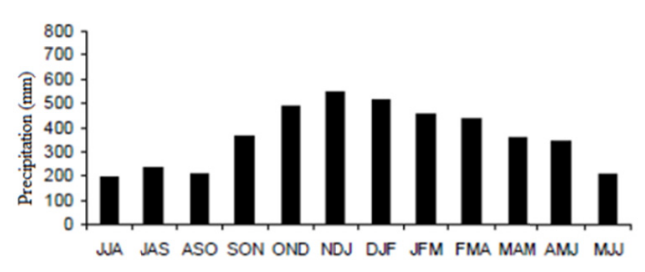


2010/2011

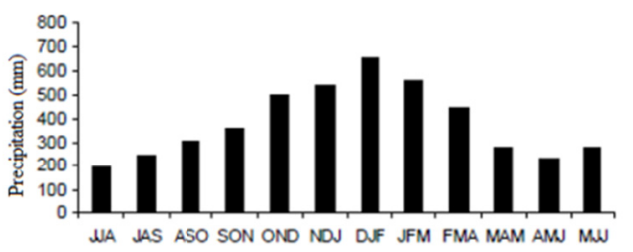

$2012 / 2013$

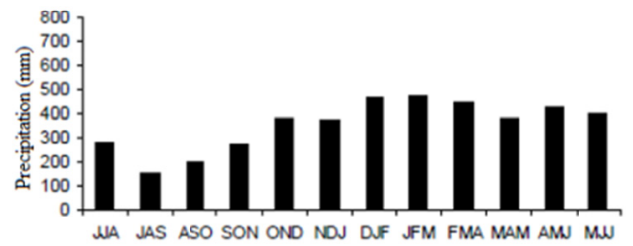

WA JAS ASO SON OND NDU D.FF JFM FMA MAM AMN $\mathrm{MW}$
2011/2012

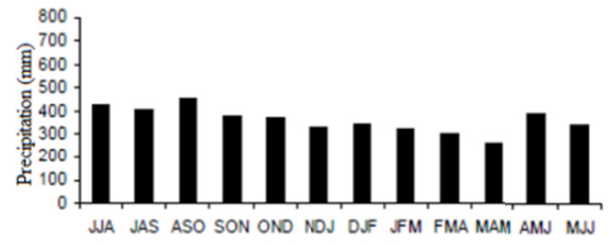

2013/2014

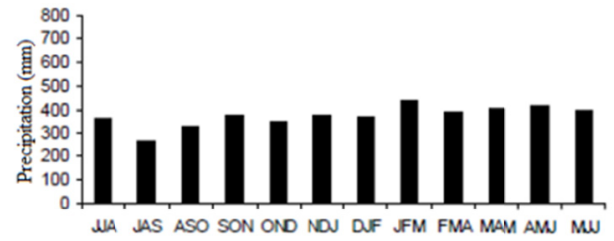

$2014 / 2015$

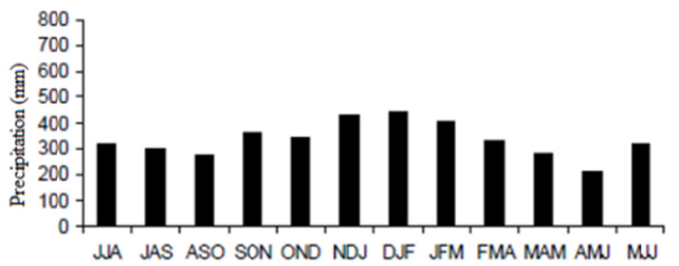

Figure 3. Rainfall precipitation accumulated quarterly (mm) in the seasons from 2004/2005 to 2014/2015, in the State of Paraná, Brazil

The occurrence of Asian soybean rust in Mato Grosso state were higher in 2009/2010, 2011/2012 e 2012/2013 seasons, with first occurrence in the months of November, October and October, respectively (Figure 4).

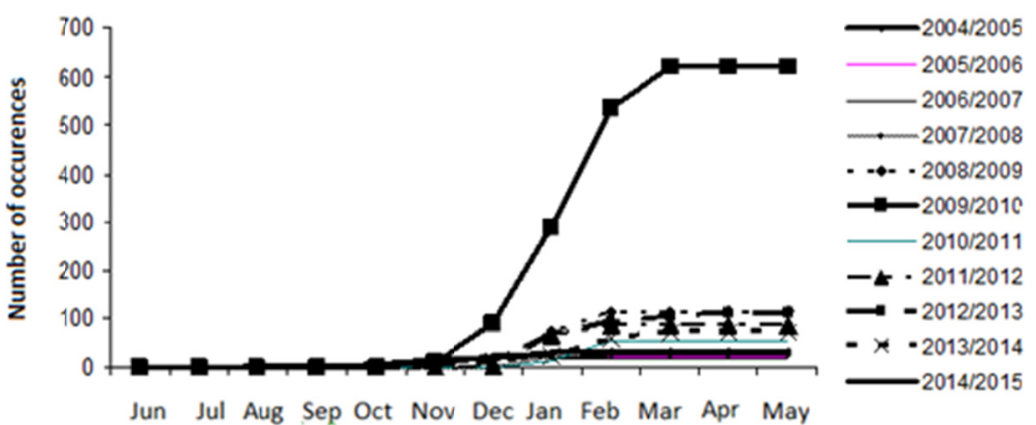

Figure 4. Cumulative Asian soybean rust occurrences in the seasons between 2004/2005 and 2014/2015 obtained from the antirust Consortium database for Mato Grosso State (Asian Soybean Rust Consortium, 2015)

According to Brazil/INPE (2015), the 2004/2005, 2006/2007 and 2009/2010 seasons were considered such as El Niño event with low intensity, while the 2007/2008 season presented the La Niña event with high intensity. The occurrence of El Niño suggests the higher rainfall volume in the southern region of Brazil and La Niña the higher rainfall volume in the north and northeast regions (Kousky, Kayano, \& Cavalcanti, 1984). In spite of this, the location of Mato Grosso state between south and north regions, demonstrated that for the El Niño only 2009/2010 season fallow expectations (Figure 5). 
2004/2005

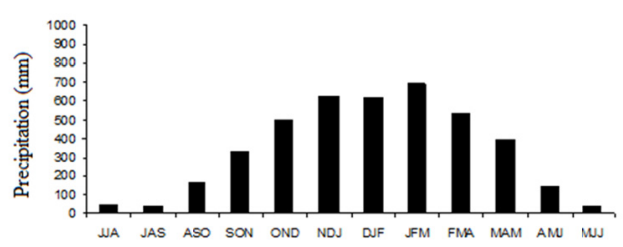

2006/2007

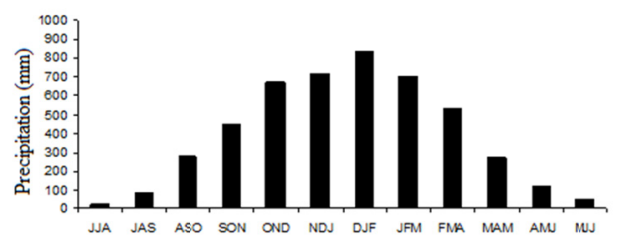

2008/2009

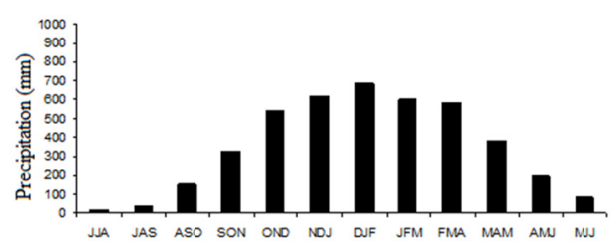

2010/2011

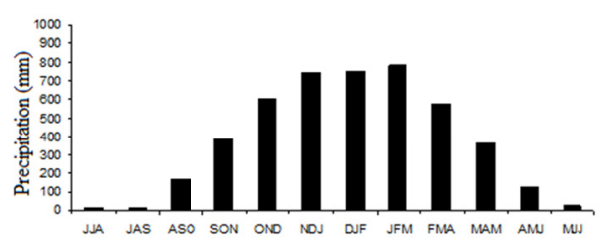

2012/2013

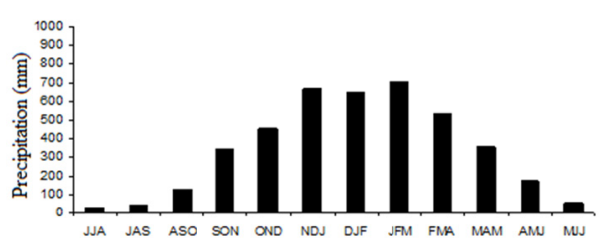

2005/2006

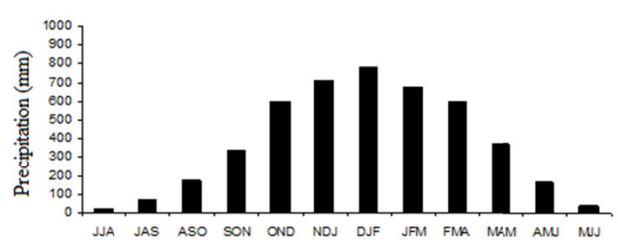

2007/2008

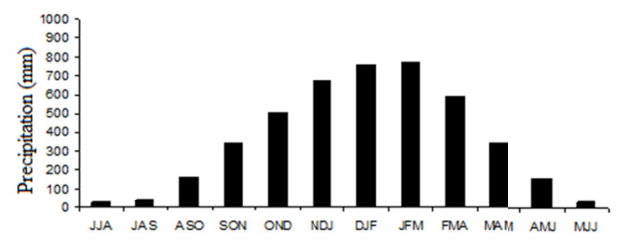

2009/2010

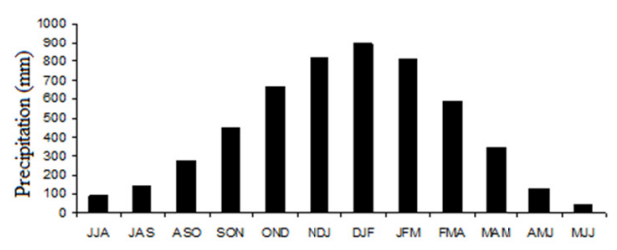

2011/2012

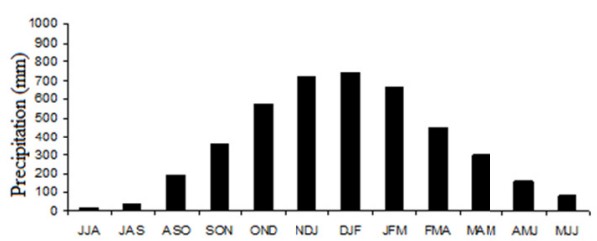

2013/2014

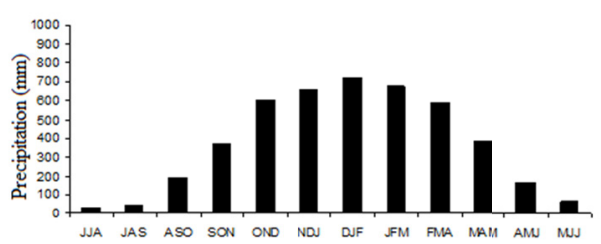

2014/2015

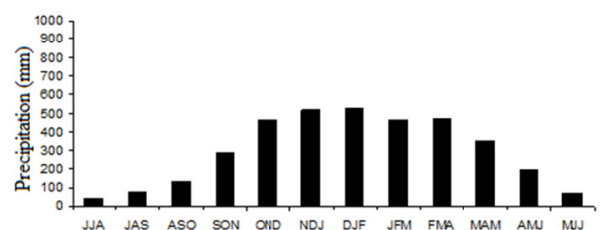

Figure 5. Rainfall precipitation accumulated quarterly (mm) in the seasons from 2004/2005 to 2014/2015, in the State of Mato Grosso, Brazil 


\subsection{Statistics and Data Analysis}

The coefficients used in the models are independent variable " $X$ " (occurrence of soybean rust in the "off season" period) with independent variable "Y" (climatic variables in the "Season" period) and their effects on the occurrence of soybean rust in the "Season" period for math constant different and equals zero.

The best models for Paraná state describes were represented by the average quarterly values of the climate variability index SST Niño 3.4 Season $\left(\mathrm{R}^{2}=0.87\right)$. The 3D models are useful to explore the relationship between variables and to define predictive variables of major importance (Canteri \& Godoy 2005; Igarashi, França, Aguiar e Silva, Igarashi, \& Abi Saab, 2016).

The outcomes of Paraná state developed models (Table 1) presented a high correlation of climate variables for linear and quadratic polynomial regression for both mathematical constants. The SPI-3 climate variable had the highest coefficient of determination $\left(R^{2}\right)$, which was equal to 0.78 , and was significant $(p<0.01)$ when used in a linear polynomial regression with a constant of zero.

Table 1. Coefficients of determination $\left(\mathrm{R}^{2}\right)$ and $\mathrm{p}$-values for linear and quadratic polynomial regressions released by soybean rust occurrence in the season, off-season and climatic variables collected between 2004 and 2015 in state of Paraná, Brazil

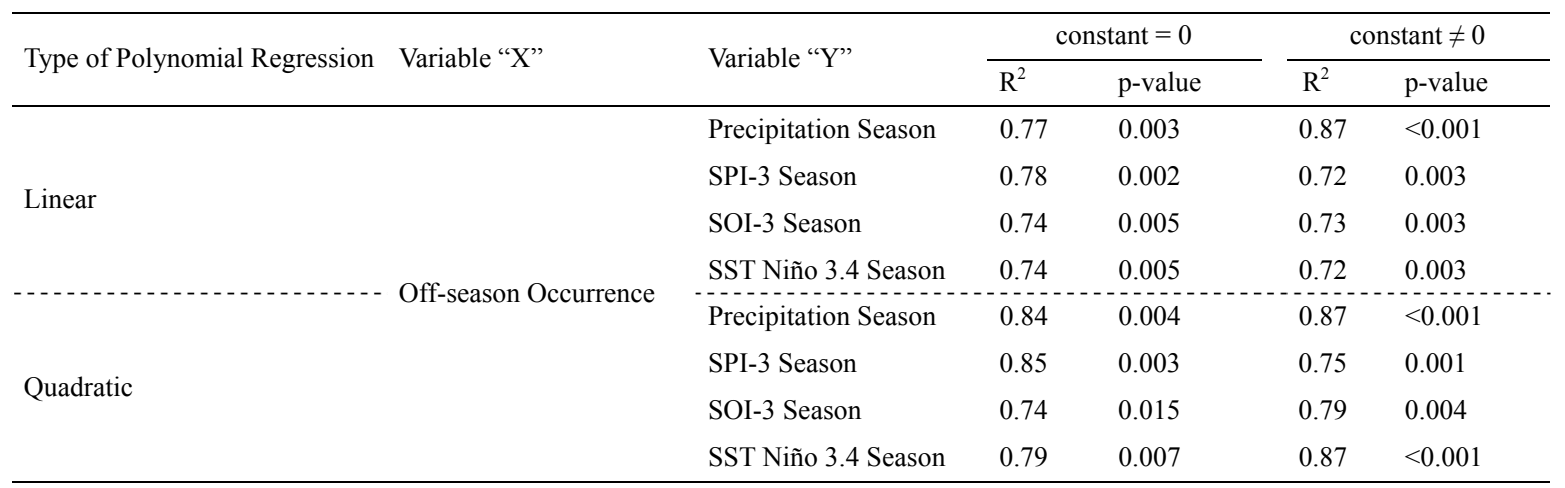

For non-zero values, the season precipitation variable had a higher $\mathrm{R}^{2}(0.87)$. The other climate variables presented an $\mathrm{R}^{2}$ between $0.72-0.77$ and were significant $(\mathrm{p}<0.01)$. The linear regression model was the preferred model to present the highest and lowest $\mathrm{p}$-value of $\mathrm{R}^{2}$, which in this case happened to be the climate variable of rainfall in the "season" period.

The models for Mato Grosso state also presented a high correlation of climate variables for linear and quadratic polynomial regression for both mathematical constants, however, the higher correlation was observed for SOI-3 Season and SST Niño 3.4. The variables of the season rainfall and SST Niño 3.4 Season presented the highest $\mathrm{R}^{2}$ index for a quadratic polynomial regression, which 0.87 and 0.96 for Paraná and Mato Grosso, respectively (Table 2).

Table 2. Coefficients of determination $\left(\mathrm{R}^{2}\right)$ and $\mathrm{p}$-values for linear and quadratic polynomial regressions released by soybean rust occurrence in the season, off-season and climatic variables collected between 2004 and 2015 in state of Mato Grosso, Brazil

\begin{tabular}{|c|c|c|c|c|c|c|}
\hline \multirow{2}{*}{ Type of Polynomial Regression } & \multirow{2}{*}{ Variable "X" } & \multirow{2}{*}{ Variable "Y" } & \multicolumn{2}{|c|}{ constant $=0$} & \multicolumn{2}{|c|}{ constant $\neq 0$} \\
\hline & & & $\mathrm{R}^{2}$ & p-value & $\mathrm{R}^{2}$ & p-value \\
\hline \multirow{4}{*}{ Linear } & \multirow{8}{*}{ Off-season Occurrence } & Precipitation Season & 0.91 & $<0.001$ & 0.95 & $<0.001$ \\
\hline & & SPI-3 Season & 0.91 & $<0.001$ & 0.92 & $<0.001$ \\
\hline & & SOI-3 Season & 0.93 & $<0.001$ & 0.95 & $<0.001$ \\
\hline & & SST Niño 3.4 Season & 0.92 & $<0.001$ & 0.93 & $<0.001$ \\
\hline \multirow{4}{*}{ Quadratic } & & Precipitation Season & 0.92 & 0.001 & 0.95 & $<0.001$ \\
\hline & & SPI-3 Season & 0.92 & $<0.001$ & 0.92 & $<0.001$ \\
\hline & & SOI-3 Season & 0.94 & $<0.001$ & 0.96 & $<0.001$ \\
\hline & & SST Niño 3.4 Season & 0.94 & $<0.001$ & 0.96 & $<0.001$ \\
\hline
\end{tabular}




\section{Discussion}

The results confirmed the influence of rainfall on the epidemic (Tsukahara, Hikishima, \& Canteri, 2008; Del Ponte \& Esker, 2008; Megeto, Oliveira, Del Ponte, \& Meira, 2014). However, considering the off-season period, the amount of initial inoculum also explains the positive effects on the season period. The results also showed that the regressions using several cases in the off-season (initial inoculum) other than zero showed higher coefficients of determination, which better explains the number of cases that occurred during the season. The Figure 2 suggesting which the increase of occurrence in the season was directly influenced by the off-season occurrence. The increased focus on the number of ASR occurrences in the off-season is justified because it will enable development of possible models for predicting the disease.

Problems in the estimation of the initial inoculum may underestimate or overestimate the epidemic. Campbell and Madden (1990) noted that the amount of the initial inoculum is a limiting factor for the evolution of the epidemic. Berger (1981) worked with disease simulation models and mentioned that the accuracy and precision of the models at the end of the epidemic was influenced by the amount of the initial inoculum estimated at the beginning of the calculations. Upper and Pfender (2015) developed a disease simulation model and estimated the initial inoculum from subsequent observations when the first symptoms were detected.

Most forecasting models use only environmental factors; these usually include hours of wetness and temperature, considering that the pathogen and host (the other vertices of the triangular disease), are always present (M. C. Alves, Pozza, Costa, Carvalho, \& L. S. Alves, 2011). In addition, the models usually not consider factors such as leaf age and susceptibility (Xavier, Martins, Fantin, \& Canteri, 2017) and plant nutrition (Gaspar et al., 2015). The present study demonstrated that the presence of inoculum (the pathogen vertex) exerts a great influence on epidemics during the season.

According to Aylor (1986), setting the arrival date of the inoculum is the main problem in the air transport of fungal spores because often, the disease cannot be observed until the pathogen has suffered one or more spore production cycles. If the initial inoculum pressure is light and the pathogen latency period is over, the disease may not be displayed until one or two weeks after the arrival of the inoculum.

Esker et al. (2007) noted that the forecast models have a limited ability to correctly estimate the presence and concentration of inoculum that will start epidemics. The authors concluded that although forecasting models are available, they still cannot function without monitoring of the spread of the disease or disclosure of outbreaks; these models also show the inoculum presence on site for real-time assessment of the disease.

In the case of P. pachyrhizi, a biotrophic pathogen, there are two possibilities for completing the pathogen vertex at the beginning of the season; the fungus either remains in host plants in the same region or comes from other regions by air. Pivonia, Yang, and Pan (2005), citing Hamilton and Stakman (1967), studied the second hypothesis for the wheat rust pathosystem. The authors observed that the time of the first disease occurrence over a number of years presented a gradual south to north occurrence. The calculated daily disease front movement from Texas to North Dakota was approximately $30 \mathrm{~km} /$ day.

Isard et al. (2011), working with the dispersal of P. pachyrhizi spores to the interior of the North American continent using collectors, cited the low potential for transport over long distances. According to Pivonia, Yang and Pan (2005), P. pachyrhizi urediniospores are coarse particles that obey the laws of gravity or rapid sedimentation or settling to the surface once released into the atmosphere. Thus, they cannot travel long distances close to the surface within the mixed boundary layer (MBL, which is when the atmosphere is influenced by surface heat exchange and turbulent mixing) (Krupa et al., 2006). For regions where host is not present during throughout year the main source of inoculum depends on spore dispersion over long distances (Pivonia, Yang, \& Pan, 2005). Already in regions where it is possible Minchio, Canteri, Fantin and Aguiar e Silva (2016) suggest that the presence of host plants in the area or in nearby areas during the off-season is one of the main responsible sources of epidemic of ASR.

Thus, evidence indicates that the variable number of occurrences in the off-season significantly influenced the model, indicating the potential use of this variable and meteorological variables on a macro scale to predict epidemics even before the start of the season

\section{References}

Alves, M. C., Pozza, E. A., Costa, J. C. B., Carvalho, L. G., \& Alves, L. S. (2011). Adaptive neuro-fuzzy inference systems for epidemiological analysis of soybean rust. Environmental Modelling \& Software, 26(9), 1088-1096. https://doi.org/10.1016/j.envsoft.2011.03.008 
Asian Soybean Rust Consortium. (2017). Consórcio antiferrugem. Retrieved August 10, 2017, from http://www.consorcioantiferrugem.net

Aylor, D. E. (1986). A framework for examining inter-regional aerial transport of fungal spores. Agricultural and Forest Meteorology, 38, 263-288. https://doi.org/10.1016/0168-1923(86)90017-1

Berger, R. D., Hau, B., Weber, G. E., Bacchi, L. M. A., Bergamin, A., \& Amorim, L. (1995). A simulation model to describe epidemics of rust of Phaseolus beans I. Development of the model and sensitivity analysis. Phytopathology, 85, 715-721. https://doi.org/10.1094/Phyto-85-715

Berlato, M. A., Farenzena, H., \& Fontana, D. C. (2005). Associação entre El Niño Oscilação Sul e a produtividade do milho no Estado do Rio Grande do Sul. Pesquisa Agropecuária Brasileira, 40(5), 423-432. https://doi.org/10.1590/S0100-204X2005000500001

Brazil/INPE. (2014). Informações sobre produtos de monitoramento climático mensal e sazonal das chuvas no Brasil na página do CPTEC/INPE. CPTEC/INPE, Cachoeira Paulista. Retrieved August 8, 2015, from http://clima1.cptec.inpe.br/ rclima1/pdf/Documento_produto_indice.pdf

Campbell, C. L., \& Madden, L. V. (1990). Introduction to plant disease epidemiology. New York, NY, John Wiley \& Sons.

Canteri, M. G., \& Godoy, C. V. (2005) Influência da severidade de mancha angular na eficiência fotossintética da área foliar sadia de feijoeiro, em condições de campo. Semina: Ciências Agrárias, 26(2), 179-186. https://doi.org/10.5433/1679-0359.2005v26n2p179

Canteri, M. G., Del Ponte, E. M., Godoy, C. V., \& Tsukahara, R. Y. (2007). Emprego de tecnologia da informação para previsão de epidemias e zoneamento agroclimático aplicáveis no controle de doenças de plantas. Summa Phytopathologica, 23, 121-124.

CONAB (Companhia Nacional de Abastecimento). (2018). Safra 2017/18-Sétimo Levantamento (pp. 1-139). Acomp. safra bras. grãos (Vol. 5). CONAB, Brasilia.

Del Ponte, E. M., \& Esker P. D. (2008). Meteorological factors and Asian soybean rust epidemics-A systems approach and implications for risk assessment. Scientia Agricola, 65, 88-97. https://doi.org/10.1590/S0103 $-90162008000700014$

Del Ponte, E. M., Godoy, C. V., Canteri, M. G., Reis, E. M., \& Yang, X. B. (2006). Models and applications for risk assessment and prediction of Asian soybean rust epidemics. Fitopatologia Brasileira, 31(6), 533-544. https://doi.org/10.1590/S0100-41582006000600001

Gaspar, G. G., Takahashi, H. W., Canteri, M. G., \& Fantin, L. H. (2015). Balance among calcium, magnesium and potassium levels affecting Asian Soybean Rust severity. Agronomy, Science and Biotechnology, 1, 39-44.

Godoy, C. V., Bueno, A. F., \& Gazziero, D. L. P. (2015). Brazilian soybean pest management and threats to its sustainability. Outlooks Pest Management, 26, 113-117. https://doi.org/10.1564/v26_jun_06

Godoy, C. V., Seixas, C. D. S., Soares, R. M., Marcelino-Guimarães, F. C., Meyer, M. C., \& Costamilan, L. M. (2016). Asian soybean rust in Brazil: Past, present, and future. Pesquisa Agropecuária Brasileira, 51, 407-421. https://doi.org/10.1590/S0100-204X2016000500002

Hamilton, L. M., \& Stakman, E. C. (1967). Time of stem rust appearance on wheat in the western Mississippi basin in relation to the development of epidemics from 1921 to 1962. Phytopathology, 57, 609-614.

Igarashi, W. T., França, J. A., Aguiar e Silva, M. A., Igarashi, S., \& Abi Saab, O. J. G. (2016). Application of prediction models of Asian soybean rust in two crop season, in Londrina, Pr. Semina: Ciências Agrárias, 37(5), 2881-2890. https://doi.org/10.5433/1679-0359.2016v37n5p2881

Isard, S. A., Barnes, C. W., Hambleton, S., Ariatti, A., Russo, J. M., Tenuta, A., ... Szabo, L. J. (2011). Predicting soybean rust incursions into the North American continental interior using crop monitoring, spore trapping, and aerobiological modeling. Plant Disease, 95, 1346-1357. https://doi.org/10.1094/PDIS-01-11-0034

Kousky, V. E., \& Cavalcanti, I. F. A. (1984). Eventos Oscilação Sul/El Niño. Características, evolução e anomalias de precipitação. Ciência e Cultura, 36(11), 1888-1899.

Kousky, V. E., Kayano, M. T., \& Cavalcanti, I. F. A. (1984). A review of the southern oscillation oceanic atmospheric circulation changes and related rainfall anomalies. Tellus A, 36, 490-504. https://doi.org/ 10.3402/tellusa.v36i5.11649 
Krupa, S., Bowersox, V., Claybrooke, R., Barnes, C. W., Szabo, L., Harlin, K., \& Kurle, J. (2006). Introduction of Asian soybean rust urediniospores into the midwestern United States-A case study. Plant Disease, 90, 1254-1259. https://doi.org/10.1094/PD-90-1254

Megeto, G. A. S., Oliveira, S. R. M., Del ponte, E. M., \& Meira, C. A. A. (2014). Árvore de decisão par classificação de ocorrências de ferrugem asiática em lavouras comerciais com base em variáveis meteorológicas. Engenharia Agrícola, 34(3), 590-599. https://doi.org/10.1590/S0100-69162014000300021

Minchio, C. A., Canteri, M. G., Fantin, L. H., \& Aguiar e Silva, M. A. (2016). Epidemias de ferrugem asiática no Rio Grande do Sul explicadas pelo fenômeno ENOS e pela incidência da doença na entressafra. Summa Phytopathologica, 42, 321-326. https://doi.org/10.1590/0100-5405/2219

Nascimento, J. F. do, Vida, J. B., Tessmann, D. J., Zambolim, L., Vieira, R. A., \& Oliveira, R. R. de. (2012). Progress of Asian soybean rust and airborne urediniospores of Phakopsora pachyrhizi in southern Brazil. Summa Phytopathologica, 38(4), 280-287. https://doi.org/10.1590/S0100-54052012000400002

Pfender, W. F., \& Upper, D. (2015). A simulation model for epidemics of stem rust in ryegrass seed crops. Phytopathology, 105, 45-56. https://doi.org/10.1094/PHYTO-03-14-0068-R

Pivonia, S., Yang, X. B., \& Pan, Z. (2005). Assessment of epidemic potential of soybean rust in the United States. Plant Disease, 89, 678-682. https://doi.org/10.1094/PD-89-0678

$\mathrm{R}$ Core Team. (2016). R: A language and environment for statistical computing. R Foundation for Statistical Computing, Vienna, Austria.

Reis, E. M. (2004). Previsão de doenças de plantas (p. 316). Passo Fundo: UPF.

Tao, Z., Malvick, D., Claybrooke, R., Floyd, C., Bernacchi, C. J., Spoden, G., ... Krupa, S. (2009). Predicting the risk of soybean rust in Minnesota based on an integrated atmospheric model. Int J Biometeorol, 53, 509-521. https://doi.org/10.1007/s00484-009-0239-y

Tsukahara, R. Y., Hikishima, M., \& Canteri, M. G. (2008). Relationship between climate and the progress of the asian soybean rust (Phakopsora pachyrhizi) in two micro-regions of Paraná State. Semina: Ciências Agrárias, 29(1), 47-52. https://doi.org/10.5433/1679-0359.2008v29n1p47

Xavier, S. A., Martins, D. C., Fantin, L. H., \& Canteri, M. G. (2017). Older leaf tissues in younger plants are more susceptible to soybean rust. Acta Scientiarum Agronomy, 39(1), 17-24. https://doi.org/10.4025/ actasciagron.v39i1.30638

\section{Copyrights}

Copyright for this article is retained by the author(s), with first publication rights granted to the journal.

This is an open-access article distributed under the terms and conditions of the Creative Commons Attribution license (http://creativecommons.org/licenses/by/4.0/). 